\title{
Songpan Garze fold belt: New petrological and geochronological data
}

\author{
Audrey Billerot ${ }^{1 *}$, Julia de Sigoyer ${ }^{2}$, Stéphanie Duchêne ${ }^{3}$, Olivier Vanderhaeghe ${ }^{1}$ \\ and Manuel Pubellier ${ }^{2}$
}

\author{
1 G2R, Nancy Université, FRANCE \\ 2 ENS-CNRS, Labo. Géologie, 75005-Paris, FRANCE \\ 3 CRPG, Nancy, FRANCE \\ * For correspondence, email: audrey.billerot@g2r.uhp-nancy.fr
}

The Songpan Garze fold belt, located in the north Tibet, is the most enigmatic block of the Tibetan plateau. It is located between the Qaidam block (to the North), the Qiangtang block (to the South) and the Yangtze block (to the East). It has been accreted to Eurasia during the Indosinian orogeny in the upper Trias. The Songpan Garze block mainly consists of deformed Triassic flyschoid sediments (5-15 km thick). Many granitoids cross cut the Songpan Garze flysch. Some of them present the same isotopic signature than the Yangtze block basement (Zhang et al. 2006, Zhang et al. 2007). The Songpan Garze block is interpreted as a relict of the Yangtze peninsula, crushed between Qaidam and Qiantang blocks during the PaleoTethys closure. Songpan Garze sediments were deposited as submarine fan in the depression comprised between the converging blocks (Roger et al. 2008).

In the Danba area (Sichuan Province China), north-west to the Longmen Shan belt (that represents the eastern boundary of the Tibetan plateau) high grade metamorphic rocks are outcropping. Those metamorphic terrains could represent a cross section of exhumed deep structure of the Songpan Garze block. Petrological and geochronological studies carried on by Huang et al. (2003a) and Huang et al. (2003b) show a polyphased metamorphic evolution. M1 stage is characterized by the occurrence of kyanite and garnet $\left(3-5 \mathrm{~kb} 570-600^{\circ} \mathrm{C}\right)$. It is dated at $204-190 \mathrm{Ma}$ and is thus related to the Indonisian orogeny. M2 stage is characterized by heating, rocks reached the sillimanite grade and migmatitic conditions (4.8-6.3 kb 640-725 ${ }^{\circ} \mathrm{C}$ )(Huang et al., 2003b) and is dated at 168-158 Ma. However, Wallis et al. (2003) obtained an age of $65 \mathrm{Ma}$ (on monazite that contain inclusions of sillimanite) for a high grade metamorphism event close to Danba. The question of the age of high temperature is then a matter of debate.

In the Quingaling dome (North Danba), migmatites of sedimentary rocks are observed. Field observations suggest that migmatization also affected metabasic intrusions. We are processing a petrogical and geochemical study on this metamorphic dome in order to precise the successive P-T conditions, and to determine if the basic intrusions are the cause of heating or if they are affected by the migmatization (partial melting or crystallization).

Moreover, cathodoluminescence observations of zircons from a leucosome of the Quingaling dome reveal growth zoning that correspond to different step of crystallisation. We interpreted them as metamorphic overgrowth around an inherited core. The different sub-domain will be dated by U-Pb dating (SIMS Cameca 1270).

\section{References}

Huang, M., Maas, R., Buick, I.S. and Williams, I.S., 2003a. Crustal response to continental collisions between the Tibet, Indian, South China and North China blocks: geochronological constraints from the Songpan-Garze Orogenic Belt, Western China. Journal Of Metamorphic Geology 21(3): 223-240

Huang, M.H., Buick, I.S. and Hou, L.W., 2003b. Tectonometamorphic evolution of the eastern Tibet Plateau: Evidence from the central Songpan-Garze Orogenic Belt, western China. Journal Of Petrology 44(2): 255-278

Roger, F., Jolivet, M. and Malavieille, J., 2008. Tectonic evolution of the Triassic fold belts of Tibet. Comptes Rendus Geoscience 340: 180-189.

Wallis, S. et al., 2003. Cenozoic and Mesozoic metamorphism in the Longmenshan orogen: Implications for geodynamic models of eastern Tibet. Geology 31(9): 745-748

Zhang, H.F., Harris, N., Parrish, R. and Zhang, L., 2006. Association of granitic magmatism in the Songpan-Garze fold belt, eastern Tibet Plateau: Implication for lithospheric delamination. Geochimica Et Cosmochimica Acta 70(18): A734-A734

Zhang, H.F. et al., 2007. A-type granite and adakitic magmatism association in Songpan-Garze fold belt, eastern Tibetan Plateau: Implication for lithospheric delamination. Lithos 97(3-4): 323-335 